\title{
PREVENTIVE AND SOCIO-EDUCATIONAL WORK OF SOCIAL PEDAGOGUES IN PRIMARY AND SECONDARY SCHOOLS IN THE SLOVAKIA
}

\author{
Ingrid Emmerová
}

\begin{abstract}
The study deals with the issue of preventive and socio-educational work of social pedagogues in schools in the Slovak republic. The current situation raises the social need for increased effectiveness of prevention and its professionalization in schools. It is therefore necessary to carry out socio-educational preventive activities in contemporary schools, where the school's social educator's plays an important role. The aim of the study was analyses legislative possibilities and actual activities of social pedagogues in schools in Slovakia.
\end{abstract}

\section{Keywords}

prevention, socio-educational work, social pedagogue, school social pedagogue

In recent decades, a number of major social changes occurred in the Slovak Republic, which has been reflected in human behaviour. We have opened up, not only to the world, but also to the world of socio-pathological phenomena. As a result of socio-economic development, there is an increase in negative social phenomena, from minor behavioural problems to severe socio-pathological phenomena. The spectrum of socio-pathological phenomena is extensive and endangers pupils from primary and secondary schools.

The increase in behavioural problems and risks among children and youth is also reflected in the daily work of teachers in primary and secondary schools. The first problems are beginning to emerge and manifest in pupils of earlier age. Typical features of their behaviour are a lack of empathy, increased aggression, a lack of self-control, selfishness, the rise of consumerism and demands for immediate compliance with their wishes.

School, primarily primary school, has an important role as it is attended by the entire population at the age of 6 and over, with a few rare exceptions. The school fulfils a number 
of functions and it is dominant educational and socialization agent. It is therefore necessary to carry out socio-educational preventive activities in contemporary schools (Janiš, Jr. \& Skopalová, 2017), where the school's social educator's plays an important role.

Work of social pedagogues in schools in the Slovak Republic is already legislatively approved. According to law Act No. 245/2008 Coll., on Upbringing and Education, in article 130 included social pedagogue to other components of the system of educational consultancy and prevention and Act No. 317/2009 Coll., on Pedagogical Staff and Specialists incorporated it into the category of professional staff. As stated in article 24: "Social pedagogue carries out professional activities within the framework of prevention, intervention and the provision of consultancy particularly for children and pupils endangered by socio-pathological phenomena, coming from socially disadvantaged background, drug addicts or otherwise disadvantaged children and pupils, their legal representatives and teaching staff of schools and school facilities. The Social pedagogue fulfils the role of social education, the promotion of pro-social, ethical behaviour, sociopedagogic diagnostics of background and relationships, socio-pedagogic consulting, prevention of socio-pathological phenomena and behavioural re-education. He/she performs expert and educational activities." Thus, the social pedagogue is an expert, who should implement prevention, intervention and consulting and should intensively work with pupils from socially disadvantaged background or otherwise disadvantaged or endangered pupils. "Numerous tasks consequently emerge for social work and social pedagogy in the school context." (Heimgartner \& Sting, 2013)

Based on my own research as well as analyses of activities of social pedagogues working in primary and secondary schools (social pedagogues no longer work in schools in Banská Bystrica, Lučenec, Trenčín et al.), the basic activities of social pedagogue in the school environment in compliance with valid legislation should be based on:

- implementing primary prevention of the socio-pathological phenomena in schools, where behavioural problems occur, and in implementing the secondary prevention,

- in active participation in the solution of behavioural problems among pupils,

- he/she should pay a special attention to pupils coming from socially disadvantaged background and actively work with them,

- cooperation with parents,

- social consulting,

- cooperation with experts,

- the field of mediation at conflicts.

Implementation of socio-pathological phenomena prevention may be considered to be the dominant field of socio-educational activity of social pedagogue in school. Professional experts (teachers, psychologists, helping professionals) report a rapid increase in behavioural problems. Such behaviour of children and youth is increasingly more daring and unfortunately more brutal. For that reason, there is a growing need for effective prevention, especially primary, and as such behaviour is widespread, as well as a need for solutions of the secondary prevention, in which school plays one of the most 
important roles. Prevention of socio-pathological phenomena must be systematically implemented on a professional level. Also Blaštíková, Skopalová and Zelinka (2015, p. 18) stress the necessity of school primary prevention. Within this context, it is necessary to specially emphasize the social pedagogue in schools as he/she has professional knowledge for the implementation of not only primary, but also secondary prevention as well as other socio-educational work. At present, the core responsibility for the implementation of prevention in Slovak schools is in hands of prevention coordinators. It refers to teachers, mostly full-time, who are not paid for performance of these duties and often do not have the required education. However, the increase of socio-pathological phenomena in children and youth requires the professionalization of prevention already in the school environment, where the social pedagogues, are professionally skilled for this activity from the time of university studies.

Another field of work of social pedagogue is to deal with the behavioural problems of pupils in primary and secondary schools. The thing is, that a versatile spectrum of unsuitable, problematic behaviour does not have to be classified into a group of behavioural disorders or socio-pathological phenomena. This includes: thefts, property damage and vandalism, delinquency (when a pupil comes into conflict with the law), aggression and bullying, truancy, running away and vagrancy, lies and cheating, the use of legal or illegal drugs, inadequate use of computers, internet or cell phone and other potential sources of non-substance addictions, sexual high-risk behaviour and others.

The current situation of the problem of the behavioural problems and risks among children and adolescents may be presented based on the results of objective researches, for example aggressive behaviour (Kušević \& Melša, 2017; Valois, Zullig, \& Revels, 2017; von Grundherr, Geisler, Stoiber, \& Schäfer, 2017), new negative phenomena - cyber bullying, sexting (Dulovics \& Kamenská, 2017; Kerstens \& Veenstra, 2015; Tomczyk \& Kopecký, 2016). In the current school practice, rare is not even aggressive behaviour of pupils towards teachers, which fact has been pointed out by several authors (Csémy, Hrachovinová, Starostová, \& Čáp, 2014; Espelage et al., 2013; Garrett, 2014; Kopecký \& Szotkowski, 2017 and others).

There are effective methods and approaches sought after to adequately address the behavioural problems. Some methods of intervention are only suitable for certain problems or behaviour disorders, for certain school environments or certain kinds of teachers and pupils (e.g. regarding the age of the pupils). Professional competence and practical experience of the teachers, the social pedagogue or school psychologist are decisive when selecting strategies. The Social pedagogue as a helping professional is qualified to work with pupils and their behavioural problems by means of re-education and re-socialization activities.

In the field of socio-educational care in school, it is necessary to pay adequate attention to pupils coming from socially disadvantaged background and to actively work with them. According to the legislation in force, social pedagogue often performs field socio-educational work too. The Social pedagogue should pay special attention to Roma pupils coming from the families which do not accept commonly established social 
norms and do not provide adequate conditions for the development of their children. At present, despite the school institutions' efforts to actively involve parents in school life as often as possible, there still persists a number of barriers and prejudices in relation to family and school, especially in the Roma families. Also collaboration with the family from the segregate Roma settlements is especially problematic. Janiš, Jr. and Kolaříková (2015, p. 89) emphasize this fact too. Collaboration between schools and families is one of the crucial area's of socialization of a child. As Kopčanová (2014, p. 29) states, from the attributes of the failures of Roma children in school, it is evident, that parents' attitude to education is essential. If the genuine cooperation between parents and school is established, the positive results are being developed in that, there is greater trust between school and family. Parents and family work together as a team to create a positive experience for students learning and the pupils enjoy the work as a result of the adults' cooperative teams.

At present, the improvement of collaboration and interconnection of school and the family in general, and particularly in the field of prevention of socio-pathological phenomena, is becoming an important requirement. This requirement is necessary when solving behavioural problems of a pupil. Also, collaboration with the family of the pupils coming from socially disadvantaged background is especially urgent. Good collaboration with parents supports the effectiveness of the teacher's work and the work of other experts with pupil. Collaboration should be based on cooperation and effective communication. Mutual acceptance, respect and tolerance should be a part of relationship. School and the family should work together in various forms. Individual forms of collaboration include invitation of parents to schools, visits to the families, individual conversation, pupil's record book and other forms of written correspondence. Collective forms of collaboration include parent teacher association (the most widespread collective form of collaboration of school and family), open days, discussions and other activities organized by the school.

There are various ideas of teachers and parents, often considerabely different, teachers and parents in division of powers and responsibilities for pupils' upbringing. Obstacles relevant cooperation exists not only on the parents' side, but also on the teachers' side. The problem of cooperation between school and family has unrealistic expectations of parents from the school perspective and vice versa. There are some examples of unrealistic expectations in terms of prevention which may be given. For example, the school sees prevention in this field of care alone and parents do not have to deal with it (on the parents' side), or parents can themselves even without expert assistance in time identify and handle problems with substance abuse with their child and prevent selfsufficiently. (unrealistic expectations on the part of the parents).

Cooperation between the school and family always depends on the cooperation of a particular teacher with a particular parent. School willingness for creating suitable conditions for cooperation also has an important position. School social pedagogue could contribute to the improvement of this situation, too. As Blaštíková (2016, p. 8) states, most of the primary schools with social pedagogue in Czech Republic, have higher 
percentage of Roma pupils. Cooperation with family coming from socially disadvantaged background is challenging, which has been confirmed also by findings of the State School Inspection. Parents concentrate their duties only to care about material provision for their children and are less concerned with their upbringing and education results, compulsory school attendance or assistance in home preparation classes for school.

A good relationship between family and school may be accomplished by:

- Sending literature to the families, which includes curriculum plan and the contact person from the school staff.

- Providing more extensive guides describing school traditions, opportunities for parental participation in the school and so on.

- Performance of open days.

- Communication of parent-teacher meetings and home visits.

- Engaging parents in teaching and counselling - as voluntary school co-workers.

- Establishment of consulting centres for parents.

- Informal social meetings.

- Active work of social pedagogue with the family of pupil.

Social pedagogue working at primary or secondary schools can provide social consulting for pupils, parents, teachers and educators. In addition to assistance, he/she is authorized to provide contacts of other experts from the helping professions field. Social pedagogue provides socio-pedagogical consulting for pupils, teachers and parents. Also, consulting for pupil with a problem is especially helpful. School social pedagogues with experience point out the fact that they are the people, who listen to pupils and to whom those pupils can confide.

Another field of his work is the cooperation with experts, mainly in the prevention and solution of behavioural problems of pupils. Solving behavioural problems of pupils is difficult and lengthy. It requires considerable patience and expertise. Various facilities and institutions provide help to school and family when solving behavioural problems. Schools, when preventing and solving behavioural problems, collaborate with several specialists, experts, institutions and suchlike. Schools often collaborate with facilities of educational consulting and prevention. Also, collaboration between schools and the Slovak Police Force is beneficial. Such a collaboration is chiefly organised by the work of policemen who are in the field of prevention. Prevention but particularly in the resolution of behavioural problems, schools collaborate with the Office of Labour, Social Affairs and Family, especially with the Department of Socio-legal Protection and Guardianship. The Social pedagogues in schools should be the one who are capable of giving advice to teachers or parents of pupil, with whatever problem and when needs to turn to these experts.

Social pedagogues are mediators at school, that is, they are a neutral person, who can help conflicting parties to negotiate a settlement of the dispute in the school environment.

According to empirical findings of Hroncová (2017, p. 24), social pedagogues working in schools, appreciate the fact that they can pay special attention mainly to problematic pupils and to pupils coming from socially disadvantaged background. In this regard, 
they help not only these pupils, but also their parents and the school itself and especially teachers who can implement the undisturbed pedagogic-educational process.

\section{Conclusion}

Social pedagogue as a helping professional - not a teacher, is helpful in many areas in the school, he/she helps pupils, teachers and parents as well. The work of a social pedagogue in school is especially beneficial for pupils with behavioural problems and for pupils coming from socially disadvantaged background because socio-educational work makes the process of socialisation easier.

School practice confirms the rationale function of school social pedagogue, which among other things enables the teachers to perform better upbringing and an educational process of higher quality. Among the positives of the work of school social pedagogues are: reduction in truancy, decreased number of aggressive behaviour by pupils, ease of communication with professional organizations, institutions and offices for director, improvement of cooperation with parents and other.

It would be desirable to create a place of a social pedagogue in each fully-organized primary and secondary schools as he/she has professional qualifications for the implementation of primary and secondary prevention as well as other socio-educational work. The social pedagogue knows the risk and protective factors of the optimal development of children and youth and he/she should influence personal development of pupils and develop their social skills.

\section{References}

Blaštíková, L., Skopalová, J., \& Zelinka, J. (2015). Competence of primary schools in the prevention of risk behaviour - school prevention methodologist. Social Pathology \& Prevention, 1(2), 11-38.

Blaštíková, L. (2016). Zkušenosti sociálního pedagoga [Experience of Social Pedagogue]. Prevence [Prevention], 2016(1), 8-9.

Csémy, L., Hrachovinová, T., Starostová, O., \& Čáp, P. (2014). Agresivní chování ve školách ČR z pohledu učitelů a žáků 2. stupně základních škol [Aggressive Behaviour in Schools in the Czech Republic from the Perspective of Teachers and Junior High School Pupils]. Prague: Centrum výzkumu protidrogových služeb a veřejného zdraví [Research Centre of Anti-Drug Services and Public Health]. Retrieved from www.cepros.cz

Dulovics, M., \& Kamenská, J. (2017). Analysis of cyber-bullying forms by aggressors in elementary and secondary schools. The New Educational Review, 49(3), 126-137. 
Espelage, D., Anderman, E. M., Brown, V. E., Jones, A., Lane, K. L., McMahon, S. D., ... Reynolds, C. R. (2013). Understanding and preventing violence directed against teachers: Recommendations for a national research, practice and policy agenda. American Psychologist, 68(2), 75-87.

Garrett, L. (2014). The student bullying of teachers: An exploration of the nature of the phenomenon and ways in which it is experienced by teachers. Aigne, 5(1), 19-40.

Heimgartner, A., \& Sting, S. (2013). The establishment of school social work in Austria - From a project to a regular offer. Center for Educational Policy Studies Journal, 3(2), 119-134.

Hroncová, J. (2017). Sociálny pedagóg v škole - jeho profil, kompetencie a problémy v praxi [Social Pedagogue at School - Profile, Competences and Problems in Practice]. In Socialia 2017 (pp. 18-27). Banská Bystrica: Belianum.

Janiš, K., Jr., \& Kolaříková, M. (2015). Barriers to preschool education from the perspective of the parents of preschool aged children in environments at risk of social exclusion. Social Pathology \& Prevention, 1(2), 83-91.

Janiš, K., Jr., \& Skopalová, J. (2017). Profesní připravenost učitelů základních škol $\checkmark$ oblasti řešení rizikového chování a možnosti jeho prevence $v$ Moravskoslezském kraji. I. Pedagogické aspekty [Professional Preparedness of Teachers in the Area of Risk Behaviour and Its Prevention in the Moravian-Silesian Region. I. Pedagogical Aspects]. Opava: Faculty of Public Policies in Opava, Silesian University in Opava.

Kerstens, J., \& Veenstra, S. (2015). Cyber bullying in the Netherlands: A criminological perspective. International Journal of Cyber Criminology, 9(2), 144-161.

Kopčanová, D. (2014). Predbežná analýza depistáže detí zo sociálne znevýhodňujúceho prostredia [Preliminary Analysis of a Screening Test ofChildren from Socially Disadvantaging Environment]. In Komplexný poradenský systém prevencie a ovplyvňovania sociálnopatologických javov $v$ školskom prostredí [Complex Counselling System of Prevention and Moderation of Socio-Pathological Phenomena in School Environments] (no. 4, pp. 28-39). Bratislava: Výskumný ústav detskej psychológie a patopsychológie [Research Institute for Child Psychology and Pathopsychology].

Kopecký, K., \& Szotkowski, R. (2017). Cyberbullying, cyber aggression and their impact on the victim - The teacher. Telematic and Informatics, 34(2), 506-517.

Kušević, Z., \& Melša, M. (2017). Aggression in children and adolescents. Socijalna Psihijatrija, 45(2), 105-116. 
Správa o stave vytvárania podmienok inkluzívneho vzdelávania pre žiakov zo sociálne znevýhodneného prostredia v základných školách v školskom roku 2014/2015 v SR [Report on the State of Creating Conditions for Inclusive Education of Pupils from Socially Disadvantaged Environments in Elementary Schools in the School Year 2014/2015 in the Slovak Republic]. (2015). Bratislava: Štátna školská inšpekcia [National School Inspection]. Retrieved from www.ssiba.sk

Tomczyk, Ł., \& Kopecký, K. (2016). Children and youth safety on the Internet: Experiences from Czech Republic and Poland. Telematics and Informatics, 33(3), 822-833.

Valois, R. F., Zullig, K. J., \& Revels, A. A. (2017). Aggressive and violent behavior and emotional self-efficacy: Is there a relationship for adolescents?. Journal of School Health, 87(4), 269-277.

von Grundherr, M., Geisler, A., Stoiber, M., \& Schäfer, M. (2017). School bullying and moral reasoning competence. Social Development, 26(2), 278-294.

Zákon č. 245/2008 Z. z., o výchove a vzdelávaní (školský zákon) a o zmene a doplnení niektorých zákonov [Act No. 245/2008 Coll., on Upbringing and Education (School Act) and on Changes and Amendments to Some Acts]. (2008).

Zákon č. 317/2009 Z. z., o pedagogických zamestnancoch a odborných zamestnancoch a o zmene a doplnení niektorých zákonov [Act No. 317/2009 Coll., on Pedagogical Employees and Professional Employees and on Changes and Amendments to Some Acts]. (2009).

\section{Author}

prof. PhDr. Ingrid Emmerová, PhD.

Faculty of Education, Catholic University in Ružomberok

Department of Pedagogy and Special Pedagogy

Hrabovská cesta 1, 03401 Ružomberok, Slovak Republic

ingrid.emmerova@ku.sk 